\title{
Opening Pandora's box: a legal analysis of the right to food in South Africa
}

\author{
Bright Nkrumah \\ Mphil Dphil \\ Research Fellow of the School of Social Sciences, University of KwaZulu Natal
}

\begin{abstract}
SUMMARY
The right to food (RTF) is a popular concept in South Africa. Its inclusion in the 1996 Constitution raised the hopes and promised a better life for many. By enshrining a broad spectrum of (civil/political and economic/ social) rights, the Constitution symbolised a commitment and a bold statement by the state to promote the fundamental rights of every individual. Nonetheless, after two decades since its adoption, the lofty ideals of the Constitution remain a pipe dream to many (who continue to face abject poverty, endemic hunger and malnutrition). It is clear that although the RTF under sections 27 and 28 is noble in purpose; its operationalisation has been fraught with several legal hurdles. To overcome these challenges, this article outlines some recommendations on how human rights activists and legal practitioners can overcome assertion often advanced against the realisation of this right. As such, there is a need to provide policy options and legal clarity on how to enforce the RTF. To this end, the paper provides claims which could be submitted before a court or domestic human rights bodies on why government must momentarily adopt reasonable steps to fulfil its obligation under section 27(1)(b).
\end{abstract}

\section{Introduction}

The main motivation for the inclusion of the concept of the right to food (RTF) in the 1996 Constitution by South Africa's democratically elected government, was the failure of its predecessor (the apartheid regime) to respond appropriately to the prevalence of food poverty (inability to produce or afford food) which plagued many black South Africans. ${ }^{1}$ In documenting the food insecurity situation of the majority of South Africans during the apartheid regime, Dugard succinctly avows that:

[a] vast web of statutes and subordinate legislation confine the African to his tribal homeland and release him only in the interest of the agricultural and industrial advancement of the white community. When he visits a 'white area' as a migrant labourer he does so on sufferance, shackled by the chains of legislation and administrative decision. ${ }^{2}$

1 The Preamble of the Constitution of the Republic of South Africa Act 108 of 1996 (the 1996 Constitution) states that "through our freely elected representative, adopt this Constitution as the supreme law of the Republic so as to improve the quality of life of all citizens and free the potential of each person".

2 Dugard Human Rights and the South African Legal Order (1978) 73.

How to cite: Nkrumah 'Opening Pandora's box: a legal analysis of the right to food in South Africa' 2019 De Jure Law Journal 47-64

http://dx.doi.org/10.17159/2225-7160/2019/v52a3 
It was against this backdrop that Nelson Mandela avowed that:

[a] simple vote, without food, shelter and health care is to use first generation rights as a smokescreen to obscure the deep underlying forces which dehumanize people. It is to create an appearance of equality and justice, which by implication socioeconomic inequality is entrenched. We do not want freedom without bread, nor do we want bread without freedom. We must provide for all the fundamental rights and freedoms associated with a democratic society. ${ }^{3}$

The 1996 Constitution, thus, provides for an unprecedented RTF for everyone, regardless of race, religion or sex. Section 27(1)(b) of the Constitution specifically provides that everyone has the right to have access to sufficient food, while section 28(1)(c) of the Constitution guarantees the right of every child "basic nutrition". 4 These provisions make the RTF undeniably justiciable. For even though section 27(1)(b) of the Constitution is watered down by subsection 2 (which entreats the state to fulfil its obligation based on available resources), there is no clawback clause limiting the enjoyment of section 28(1)(c) of the Constitution. ${ }^{5}$ Section $27(2)$ of the Constitution further imposes an obligation on the state to adopt positive measures to ensure that everyone has adequate access to food. Positive measures simply refers to the framing and operationalisation of suitable polices to enhance the fulfilment of a specific right. ${ }^{6}$ Besides the Constitution, food right is informed by a rich international law jurisprudence, ${ }^{7}$ and Constitutional Court decisions, which have demonstrated an inclination to give economic and social rights substance. ${ }^{8}$ Moreover, various pieces of sectoral legislation, related in one way or another to RTF, have also been enacted. ${ }^{9}$

Nonetheless, in stark contrast to these gains are a series of setbacks, which militate against the meaningful realisation of the RTF. The slow pace of land reform coupled with poor implementation of RTF related interventions, including poor (and inadequate) provision of social security grants imply that millions of South Africans are still confronted

3 Mandela "Address: On the Occasion of the ANC's Bill of Rights Conference" in A Bill of Rights for a Democratic South Africa: Papers and Report of a Conference Convened by the ANC Constitutional Committee (May 1991) 12. Own emphasis.

4 Unless otherwise stated, the Constitution refers to the Constitution of the Republic of South Africa.

5 Constitution ss $27 \& 28$.

6 Nkrumah Mobilizing for the realisation of the right to food in South Africa (Dphil Thesis 2017 UP) 38.

7 Social and Economic Rights Action Centre and Another v Nigeria (2001) ACHPR 60.

8 Minister of Health $v$ Treatment Action Campaign 200210 BCLR 1033 (CC).

9 DSD "National Food Emergency Scheme" 2013 http://www.dsd.gov.za/ index2.php?option $=$ com_docman\&task $=$ doc_view\&gid $=\% 20 \%$ 0B515\&I temid $=39$ (last accessed 2019-04-08); DAFF "Integrated Food Security Strategy" 2019 https://www.daff.gov.za/daffweb3/Programme/Integratedfood-Security-and-Nutrition-Programme (last accessed 2019-04-08). 
with chronic hunger and undernourishment. ${ }^{10}$ According to Statistics South Africa (StatSA), 6 million South Africans are experiencing to chronic hunger. ${ }^{11}$ This begs the question, does the government's current food programmes meet the benchmark of sections 27 and 28 of the Constitution? In order to adequately respond to this question, the paper assesses food related programmes such as social assistance programme (SAP), National Student Financial Aid Scheme (NSFAS) and school feeding programme to determine whether they comply with constitutional guarantees. In this paper, "chronic hunger", "food insecurity" and "food poverty" are used interchangeably. Indeed, this latter usage reflects the paper's preference for identifying individuals' with limited or no access to food with poverty. Before assessing how to safeguard the right of this vulnerable group, a definition of the RTF suffices.

\section{Beyond cheap promises: right to food and the Constitution}

In his 1981 landmark essay titled Poverty and Famine, Amartya Sen intimated that food insecurity is not triggered by less production of food, but rather the inability of some to afford the available food on the markets. ${ }^{12}$ He concluded that hunger cannot be alleviated by simply increasing yield, rather, by addressing the poverty situation of the marginalised and most vulnerable groups in society. ${ }^{13}$

The RTF serves as a safeguard for people to feed themselves in dignity. In order to achieve this objective, this right, further, imposes a legal obligation on the state to ensure that there is sufficient food in the local market, its citizens have the means to buy them, and they meet the dietary requirements of the people. It is a right for all and serves as a "compass" to ensure that legal frameworks and strategies are adopted and implemented towards the alleviation of hunger. ${ }^{14}$ As set out in its General Comment 12, the Committee on Economic Social and Cultural Rights (CESCR) stated that the RTF is fulfilled:

[w] hen every man, woman and child, alone or in community with others, have physical and economic access at all times to adequate food or means for its procurement. The right to adequate food shall therefore not be interpreted in a narrow or restrictive sense, which equates it with a minimum package of calories, proteins and other specific nutrients. The right to adequate food will have to be realized progressively. However, states have a core obligation to take

10 Constitution s 27(1)(b)

11 StatSA “General Household Survey” 2017 Statistical Release P0318 6.

12 Sen Poverty and Famines: An essay on Entitlement and Deprivation (1981) 154-5.

13 Sen 39.

14 De Schutter "Countries Tackling Hunger with a Right to Food Approach" 2010 UN Briefing Note 1. 
the necessary action to mitigate and alleviate hunger [...] even in times of natural or other disasters. ${ }^{15}$

At the domestic level, the 1996 Constitution represents an overarching commitment by the state to advance the RTF. Specifically, while section $27(1)(b)$ of the Constitution guarantees the rights of everyone to "sufficient food", section 28(1)(c) provides for the rights of every child to basic nutrition, and section 35(2)(e) of the Constitution further sets out the rights of every detained person and prisoner to sufficient nutrition. ${ }^{16}$ Other essential rights linked to the RTF are the rights to life, dignity, equality, work and social security. ${ }^{17}$ These far-reaching safeguards, in and of themselves, should trigger the drive towards the effective operationalisation and realisation of individual RTF.

Akin to other socioeconomic rights, section 7(2) of the Constitution imposes an obligation on the state to "respect, protect, promote and fulfil" the rights to food. ${ }^{18}$ This provision implies that the state must: (i) adopt necessary steps to ensure that everyone has access to adequate food; (ii) adopt measures to prevent third parties from breaching this right; and (iii) refrain from any action which might interfere with individual enjoyment of this right. Yet, given that millions of South Africans are food insecured, it is apparent that the state has breached the first leg of this three-legged stool. It is against this backdrop that this paper considers some of the best approaches which could foster RTF. To this end, a two-pronged approach is adopted. On the one hand, the contribution considers direct court litigation where the food insecured (otherwise, the food poor) may claim that their food right has been breached. On the other hand, it considers the possibility of a court creatively interpreting legislations as a means of safeguarding the RTF.

\section{Food for thought: claims for or against right to food}

Section 27(2) of the Constitution obliges the state to "take reasonable legislative and other measures" to achieve the RTF. ${ }^{19}$ Given that there is no universal definition of reasonableness, the Constitutional Court framed three key thresholds, which a policy must meet in order to meet the reasonable test. Such a policy must: (i) not exclude a disproportionate percentage of the population; (ii) take into consideration the situation of those in crisis; and (iii) address the needs of those in desperate condition. ${ }^{20}$ Yet, before an aggrieved group of people could approach a

15 CESCR “General Comment 12” E/C.12/1999/5, para 6; Own emphasis.

16 Constitution ss 27(1)(b), 28(1)(c) \& 35(2)(e).

17 See ss $10,11,23(2), 27(1)(c) \& 36$.

18 Constitution s $7(2)$.

19 Constitution s 27(2).

20 See Government of the Republic of South Africa \& Others $v$ Grootboom \& Others 2000 (11) BCLR 1169 (CC), paras 43, 44 \& 64. 
court with a claim that a section of their right has been breached, they must first consider how they intend to substantiate that claim.

Although it is obvious that government has failed to comply with its RTF obligation, the question of the probability of such a claim being successful stands to be contested. In order to determine the degree to which such a claim can be filed, the article turns to weigh the claims why the state must not fulfil food rights. But, before that an introspection on why it must fulfil this right is in order.

\section{Still hungry: claims for the food poor}

The celebrated economic and social rights decisions whereby the Constitutional Court expanded the scope of these rights provide the most useful benchmark against which one could test the possible success (or failure) of a RTF claim. ${ }^{21}$ It can be said that these judgments, in short, demonstrate that current legislations and programmes which (unreasonably) deny a person or a group, specific economic and social right will not pass constitutional muster. ${ }^{22}$ Perhaps, the most obvious violation which could be the subject of constitutional claim might be the failure of ongoing programmes to adequately address the needs of a certain group of desperate people. For instance, a report issued by Oxfam indicated that government's food policies have not only been fragmented and poorly implemented, but have also failed to improve the conditions of millions. ${ }^{23}$ In considering the state's economic and social rights programmes, Bilchitz avers that it is imperative for such programmes to prioritise the urgent needs of those in desperate situation, whose very survival is threatened by their present conditions. $^{24}$ This statement opens up a Pandora's box for us to reexamine cases of alleged 'desperate conditions' where one could launch a claim concerning the RTF. Four major cases come to the fore.

First, even though the key objective of SAP is to address the triple challenge of malnutrition, hunger and poverty, it excludes those without special needs. ${ }^{25}$ At the risk of stating the obvious, special needs applies to children under the age of 18 , children or adults with a specific kind of

21 Grootboom supra; Minister of Health and Others $v$ Treatment Action Campaign and Others (2002) AHRLR 189 (SACC 2002); Khosa \& Others $v$ Minister of Social Development \& Others 2004(6) BCLR 569 (CC); Soobramoney $v$ Minister of Health, KwaZulu-Natal [1997] ZACC 17, 1998 (1) SA 765 (CC), 1997 (12) BCLR 1696 (CC).

22 Chenwi \& Hardowar "Promoting Socio-economic Rights in South Africa through the Ratification and Implementation of the ICESCR and its Optional Protocol” 2010 ESR Review 7

23 Oxfam "Hidden hunger in South Africa: The faces of hunger and malnutrition in a food-secure nation" 2014 https://www.oxfam.org/sites/ www.oxfam.org/files/file_attachments/hidden_hunger_in_south_africa_0. pdf (last accessed 2019-04-08).

24 Bilchitz "Towards a Reasonable Approach to the Minimum Core: Laying the foundations for future socio-economic rights jurisprudence" 2003 SAJHR 1.

25 Constitution s 27(1)(c) 
disability, people caring for foster children, the aged, and war veterans. This special needs-based system implies that the food poor who are unable to tie their situation to natural causes such as age or disability, will not be a recipient of ongoing SAP. ${ }^{26}$ Hence, those who are excluded could launch a legal claim that since they are unable to feed themselves, the state has denied them their right to access sufficient food under section $27 .^{27}$ It was in this light that Abbey Kutumela, the first applicant in Kutumela $v$ Member of the Executive Committee (MEC) for Social Services, Culture, Arts and Sport in the North West Province, ${ }^{28}$ in his founding affidavit stated that

[w] struggle to survive, and often went hungry. Our only income at the time was what my wife could earn doing part-time domestic and cleaning work in the area. She earned about R60 per week. It was not enough to feed us. We had to beg and borrow food. ${ }^{29}$

In order to realise the RTF as well as interrelated rights (including equality and dignity of individuals whose circumstance is akin to Mr Kutumela), it is apparent that such victims of chronic hunger require urgent food assistance. ${ }^{30}$ One of the best remedies to address the circumstance of the applicants in the Kutumela case could have been the court ordering the provincial government to extend the Social Relief of Distress Grant (SRDG) to other food insecured people in the province. ${ }^{31}$ This grant, still, is inadequate since it is limited in terms of duration and application. ${ }^{32}$ The programme only provides a limited amount of food vouchers to individuals in exceptional distress for a period of three months, which can only be renewed for additional three months. ${ }^{33}$ Thus, the food poor (like Mr Kutumela), who are excluded from the conventional SAP or still face hunger after receiving a grant (due to the insufficient payout) could justifiably claim that the state's SAP does not conform to the Constitutional Court's definition of reasonableness, especially as it excludes the most desperate. ${ }^{34}$

Second, tertiary students who are food insecured and yet do not qualify or are excluded from tertiary funding, could claim that, for instance, the National Student Financial Aid Scheme (NSFAS) does not

26 Nkrumah "Averting looming tragedy: a review of the Black Sash Trust $v$ Minister of Social Development and Others" 2017 ESR Review 14.

27 Nkrumah 2017 ESR Review 15.

28 Kutumela $v$ Member of the Executive Committee for Social Services, Culture, Arts and Sport in the North West Province Case 671/2003 (unreported).

29 Kutumela $v$ MEC supra para 21 of the founding affidavit.

30 Ferguson "Formalities of Poverty: Thinking about Social Assistance in Neoliberal South Africa” 2007 ASR 86.

31 DSD "Social Relief of Distress" 2018 http://www.sassa.gov.za/index.php/ social-grants/social-relief-of-distress (last accessed 2019-04-08).

32 Nkrumah 155.

33 The SRDG was created by the 1978 Fund Raising Act 107 which provides for immediate, yet temporary material intervention to individuals or groups in distress.

34 See Grootboom supra para 33. 
meet the reasonable test as set out by the Constitutional Court. ${ }^{35}$ The students could argue that they also deserve similar school feeding programmes as their basic school counterparts since they cannot concentrate on their studies due to hunger. In so doing, it could be argued that sections 27 and (in some cases) section 28, have been infringed upon, since they have been excluded from benefiting from state resources. Hence, the fact that some tertiary students who do not have the financial means to access adequate food are denied access to study loans and bursaries appears unconstitutional and a reasonable basis for a court action.

Third, other food poor could launch a direct food claim on the basis that the operationalisation of RTF interventions have been ineffective. There exists a very useful role for legal claims whenever the government unduly delays in disbursing social grants, which has an impact on the RTF. Such a constitutional claim was demonstrated in a series of court cases filed by the aged in the Eastern Cape regarding late payment of old age pensions. ${ }^{36}$ A legal claim of this nature (by extension) will ensure that national and provincial school feeding programmes (which could be perceived as a component of the SRDG), are being operationalised effectively. For instance, an SRDG recipient can make an application for extension for a second three-month period of food stamps. ${ }^{37}$ Moreover, applicants in situations of dire poverty could claim that a denial of the extension of a SRDG for a second period is unconstitutional. This claim can equally be used to litigate against any unreasonable roll-out of government's food programmes.

Further, it is imperative that NGOs and advocacy institutions educate the food poor of their food rights and what it comprises. Such educational drive will enable the food poor to contest the constitutionality of current food interventions. It is important that all the food insecured have knowledge of their food right since insufficient information will limit their prospect of successfully arguing out their case in a court. Also, in instances where there is a lack of awareness of an existing or new policy, potential beneficiaries might not know whether they qualify to receive the grant and/or the procedure involved in the submission of an application to the appropriate court if the state deals with their grant application unfairly. ${ }^{38}$ It is in this light that two observers touted that the SRDG, for example, has been underutilised due to lack of awareness that

\section{Grootboom supra.}

36 Examples of such cases include Bushula $v$ Permanent Secretary, Department of Welfare, Eastern Cape 20002 SA 849 (E); Kotze v Minister of Health 1996 3 BCLR 417 (T); Kate v MEC for Department of Welfare, Eastern Cape, 20064 SA 478 (SCA); Mbanaga v MEC for Welfare, Eastern Cape 20021 SA 359 (SE).

37 Cluver, Gardner \& Operario "Poverty and psychological health among AIDSorphaned children in Cape Town, South Africa" 2009 AIDS Care 734.

38 Nkrumah "National Monitoring by NHRIs in South Africa" in M Mayrhofer et al International Human Rights Protection: National Human Rights Institutions - A Case Study 2016 7th Framework Programme (FP7 Collaborative Project) 98. 
such a grant exist. ${ }^{39}$ Thus, it is submitted that an improved awareness or community engagement on the grant would considerably expand the number of applicants and grant holders. NGOs and social movements are well positioned to assist worthy applicants in applying for grants as a means of accessing adequate food.

A final claim, from a procedural viewpoint, is the wide locus standi of section 38 of the Constitution read with the right to access to court as set out in section $34 .^{40}$ When section 34 is applied to cases of food insecurity, the food poor have the right to approach a court alleging an infringement of their section 27 rights, while section 38 of the Constitution provides locus standi for a very broad range of interested parties. Here, it is envisaged that one or more grounds contemplated in subsections (a) to (e) of section 38 of the Constitution could potentially provide the locus standi for food right violation. ${ }^{41}$ The claims for the food poor could be concluded with a quote from Liebenberg, who averred that should the state continuously fail to heed calls to fulfil the RTF, government departments "will be vulnerable to constitutional challenge". 42

The above recommendations for RTF could, however, be countered by a claim that none of the contemporary RTF authors in South Africa has advocated for such a legal action against the state. ${ }^{43}$ Nonetheless, simply because this claim has not conceived does not imply that it should not be put to test. This assertion is substantiated by a 2005 court case relating to gender discrimination in respect of access to SAP for the elderly. ${ }^{44}$ Prior to filing this case, one could have assumed that age difference for old age grants for men and women was a form of positive discrimination, therefore, the practice was fair and undeserving of constitutional claim. The issue only became a subject for academic scrutiny only after the applicants have approached the court. ${ }^{45}$

39 Brand "Between Availability and Entitlement: The Constitution, Grootboom, and the Right to Food" 2003 LDD 12; Van Zyl \& Kirsten "Food Security in South Africa" 1992 Agrekon 178.

40 Bailey "Judicial Discretion in Locus Standi: Inconsistency Ahead" 2010 Galway Student Law Review (GSLR) 9.

41 Khoza "Realising the Right to Food in South Africa: Not by Policy Alone - A Need for Framework Legislation" 2004 SAJHR 668.

42 Liebenberg "The Right to Social Assistance: The Implications of Grootboom for Policy Reform in South Africa" (2001) SAJHR 246.

43 None of the extensive academic writings of these scholars has suggested direct litigation, namely, S Hendriks "Food Security in South Africa: Status quo and Policy Imperatives" 2014 Agrekon 1-24; Van Zyl \& Kirsten 1992 Agrekon 170-184; Khoza "Realising the Right to Food in South Africa: Not by Policy Alone - A Need for Framework Legislation" 2004 SAJHR 664-683; Moyo "The Future of Food: Elements of Integrated Food Security Strategy for South Africa and Food Security Status in Africa" 2007 ASIL 103-108; Tung "Organic Food Certification in South Africa: A Private Sector Mechanism in Need of State Regulation" 2016 PELJ 1-48.

44 The Herald (2005-09-16) 03.

45 Krftger “'Come Back When You are 65, Sir:' Discrimination in Respect of Access to Social Assistance for the Elderly" 2006 LDD 70-81. 


\section{Is the nation listening? counter-claims against the food poor}

Although there is some merits to argue that ongoing government's food programmes are highly unreasonable, it must be noted that one key RTF policy exist, namely, the SRDG. As indicated above, this programme provides direct food assistance in the form of food stamps for a limited duration to recipients in order to counter emergency food crisis. It is important to indicate that the SRDG has somewhat improved people's access to food through the allocation of food stamps. Thus, it seems irrelevant to request an order from a court for the creation of an extra food system at this stage. Thus, if the time is not yet ripe to file a claim based on current food policies, it is imperative to frame some feasible solutions to address the needs of the food poor. It is against this backdrop that the multi-faceted approach discussed underneath, may provide some relief.

\section{What must be done: taking food insecurity seriously}

Akin to other socioeconomic rights, the RTF is tied to other fundamental rights and freedoms such as equality (section 9); dignity (section 10); life (section 11); health care (section 27(1)(a)); water (section 27(1)(b)); social assistance (section 27(1)(c)); and education (section 29). ${ }^{46}$ Thus, an obvious solution for providing greater access to sufficient food lies in improving access to these ancillary rights in ways that might positively impact on sections 27 and 28 of the Constitution. This approach requires a creative interpretation and application of laws and polices related to these rights. It was against this backdrop that Brand and Heyns avow that the RTF often finds protection through other constitutional rights, given that it is often not directly safeguarded by law or court rulings. ${ }^{47}$ This argument leads us to the next section which takes a look at some of the creative means which can be adopted by court towards the realisation of the RTF.

\section{The politics of food: Reframing national food security interventions}

Section 33 of the Constitution avers that any administrative action concerning section 27 and 28 of the Constitution must be reasonable, procedurally fair and lawful. ${ }^{48}$ Thus, any application concerning RTF should also consider measures for improving administrative justice. Put differently, people's entitlement to various economic and social rights

46 See Constitution ss 9-29.

47 Heyns \& Brand "Introduction to Socio-economic Rights in the South African Constitution” (1998) LDD 156.

48 Constitution ss $27,28 \& 33$. 
such as the RTF and the right to administrative justice should work together as a means of ensuring that all persons have lawful, procedurally fair and reasonable access to food. ${ }^{49}$ The significance of such an assessment becomes even more apparent if one accepts the connection between the RTF and other substantive economic and social rights, and their enforcement. ${ }^{50}$ If the state's feeding and nutrition programmes are to address the needs of the food poor, then the roll-out of such programmes must be fair and reasonably administered. To ensure that an administrative action is reasonable and promotes fundamental rights, a proportionality test must be conducted. ${ }^{51}$ Such an enquiry encompasses assessing the harms which will be created for not adopting certain measures, as compared to the advantages to be gained from implementing such measures. ${ }^{52}$ Undoubtedly, such a balancing act is required in administrative decision-making concerning the RTF. In other words, administrative action which promotes a generous application as well as broad interpretation of RTF is needed considering that food is a necessity for human existence. ${ }^{53}$

In terms of the requirement of procedural justice, any administrative action (in)directly impacting on individual's RTF must be supported by adequate reasons while following the prescribed steps for implementing such measures. ${ }^{54}$ Yet, any such procedural justice must also include the process being executed as expeditiously as is reasonably possible due to the fact that undernourishment have dire consequences, including the likelihood of death. ${ }^{55}$ For instance, an applicant for SRDG may suffer great hardship or even die if he/she was to wait unduly long for the reasons for the denial of his/her application, in order to submit a claim to the appropriate court challenging the administrative decision. ${ }^{56}$ It is, therefore, imperative that courts play a primary role in ensuring that all administrative decisions affecting RTF are just and fair.

49 Davis "Socioeconomic rights: do they deliver the good?" (2008) International Journal of Constitutional Law (IJCL) 703.

50 Quinot \& Liebenberg "Narrowing the band: reasonableness review in administrative justice and socio-economic rights jurisprudence in South Africa” 2011 SLR 648.

51 Contiades \& Fotiadou "Social rights in the age of proportionality: global economic crisis and constitutional litigation" (2012) International Journal of Constitutional Law (IJCL) 667.

52 Steinberg "Can reasonableness protect the poor? A review of South Africa's socio-economic rights jurisprudence" 2006 SALJ 278.

53 Stewart "Interpreting and limiting the basic socio-economic rights of children in cases where they overlap with the socioeconomic rights of others" 2008 SAJHR 479.

54 Bato Star Fishing (Pty) Ltd $v$ Minister of Environmental Affairs and Tourism 20044 SA 490 (CC) para 44.

55 Wesson "Grootboom and reassessing: beyond the socioeconomic jurisprudence of the South African Constitutional Court" 2004 SAJHR 292.

56 Liebenberg "The value of human dignity in interpreting socio-economic rights" 2005 SAJHR 13. 


\section{Job creation: means of entitlement}

Besides the strategies discussed above, one of the (in)direct approaches which could be used to enhance people's RTF is the creation of job opportunities. As income earned can be used (in)directly to produce or purchase food, the ability to earn an income is important for people to feed themselves. ${ }^{57}$ For instance, people could use their wages or salaries to buy agricultural land or farming implements. Nonetheless, the actual means through which one could generate an income fall outside the ambit of this legal assessment and will for that reason, not be taken further in this paper.

\section{Gaining ground: A call for land reform}

One of the best approaches to assist people fulfil their RTF is by improving access to agricultural land. To the extent that millions of black South Africans are living in the infertile former homeland, ${ }^{58}$ it is necessary that an efficient land reform programme is rolled out to address the food insecurity situation of most blacks. ${ }^{59}$ However, in certain parts of the country, specifically in the Eastern Cape, a contentious situation exist regarding instances where substantial parcels of land (mainly for commercial livestock) are being converted into game ranching. ${ }^{60}$ A counter-claim could, however, be mooted that South Africa's hunger situation is not so much about shortage of production but rather unequal supply of food. ${ }^{61}$ Yet, regardless of this justification, it is contentious that given the limited amount of available land for redistribution, the conversion of agricultural lands into game farms is unreasonable. ${ }^{62}$ For purposes of ensuring that local farmers have access to food, it is imperative that the state prioritises the use of land for farming purposes rather than recreational activities.

Land dispossession in terms of the threshold set out under sections 25(2) and 25(3) of the Constitution, may only occur after all relevant requirements have been satisfied (including fair compensation). ${ }^{63}$ These provisions implicitly implies that the dispossession of land meant for food production should only be considered as a last alternative. Again, where agricultural land is dispossessed from individuals for nonagricultural purposes, this factor should reflect in the amount of reimbursement given to the owner. Besides being fair, this submission is also reasonable, given that, although, a dispossession may sometimes be

57 Nkrumah in Cobbinah \& Addaney The geography of climate change adaptation in urban Africa (2019) 314.

58 Pringle "Land reform and white ownership of agricultural land in South Africa” 2013 HSF 39. Also see Mail and Guardian (2014-09-15) 04.

59 The Herald (2017-11-01) 02.

60 Farmer's Weekly (2017-009-12) 05.

61 Nkrumah IX.

62 Snijders "Wild property and its boundaries-on wildlife policy and rural consequences in South Africa” 2012 Journal of Peasant Studies (JPS) 508.

63 Constitution ss 25 (2) \& 25 (3); Keep \& Hall "Land redistribution in South Africa: Towards decolonization or recolonization?" 2018 Politikon 129. 
necessary in the broader interests of the society, any dispossession, which denies an individual's ability to feed herself, triggers the need to provide such dispossessed owner with alternative means of accessing food.

It is, also, important to indicate that land reform legislation can play a key role in the realisation of the RTF. Two of these major legislations are the Extension of Security of Tenure Act (ESTA), ${ }^{64}$ and the Prevention of Illegal Eviction and Unlawful Occupation of Land Act (PIE). ${ }^{65}$ The provisions of ESTA and PIE take great strides in enhancing the tenure of land occupiers, considering that racist policies under apartheid such as the Illegal Squatting Act, ${ }^{66}$ and Bantu Laws Amendment Act, ${ }^{67}$ "enabled the government and landowners to drive millions of urban and rural blacks from their land" ${ }^{68}$ The connection between RTF and these laws (ESTA and PIE) is that by becoming land owners through ESTA or having greater rights to lawfully possessed land, there is the likelihood to utilise this security of tenure to secure food by tilling the soil.

Such farming activities could assume either commercial or subsistence nature where the occupiers and their dependents could generate other forms of food for themselves. The obvious relation between the RTF and ESTA is clearly set out in section 1 of the Act which protects the right of rural land occupiers to engage in farming by prohibiting their arbitrary eviction. ${ }^{69}$ This point is better illustrated in the Ntshangase $v$ The Trustees of the Tereblanche Gesin Familie Trust the applicant's livestock were denied access to water and grazing on a piece of land. ${ }^{70}$ In its judgment, the court held that indeed an unlawful eviction has occurred. ${ }^{71}$

Both instruments (PIE and ESTA) further, aver that before ordering the eviction of any occupiers, an appropriate court must first consider whether such eviction is just and equitable. It is submitted that in line with sections 27 and 28 of the Constitution, in assessing such an eviction application, the court must consider the rippling effect of this act on the RTF of affected parties (and their dependents). In so doing, a court must adopt a purposive interpretation of the ESTA and PIE in view of sections 27 and 28 of the Constitution, which guarantees groups and individual's RTF. 72

\footnotetext{
64 Extension of Security of Tenure Act 62 of 1997.

65 Prevention of Illegal Eviction and Unlawful Occupation of Land Act 19 of 1998.

66 Illegal Squatting Act 52 of 1951.

67 Bantu Laws Amendment Act 7 of 1964

68 Yates "Constitutional Court delivers a vision for land restitution" 2007 ESR Review 20.

69 ESTA s 1.

70 Ntshangase $v$ The Trustees of the Tereblanche Gesin Familie Trust [2003] JOL 10996 (LCC).

71 Ntshangase $v$ The Trustees of the Tereblanche Gesin Familie Trust supra para 11 .

72 Constitution s $27 \& 28$. See Cock "A feminist response to the food crisis in contemporary South Africa” 2016 Agenda 128.
} 
Further, the Land Reform Act, PIE and ESTA enhance RTF by safeguarding land rights against its denial by private actors. ${ }^{73}$ These instruments ensure that the rights of occupiers are not unfairly denied by subjecting the process of eviction to several safety measures as well as limiting the ambit of lawful eviction. ${ }^{74}$ For instance, both PIE and ESTA aver that before any occupier is evicted, an appropriate court must first determine whether upon eviction, there is an alternative land for such persons. ${ }^{75}$ To this end, it would be fair and reasonable to apply this benchmark in all judgements, but interpreting alternate land to imply another fertile land which could be used for grazing or food production purposes.

An additional piece of legislation, which has become a matter of consideration by the Constitutional Court, is the Restitution of Land Rights Act. ${ }^{76}$ In the Department of Land Affairs $v$ Goedgelegen Tropical Fruits (Pty) Ltd, the applicants who are Popela community claimed that they had been dispossessed of their land due to the racially discriminatory practices of the apartheid regime. ${ }^{77}$ The Court held that the applicant must be granted restitution or equitable redress as contemplated by the Restitution Act, considering that as a result of the racially discriminatory laws of the past, the community were wrongfully evicted from their lands. ${ }^{78}$ This groundbreaking decision by the Constitutional Court holds great potential to improve the RTF of this community, since they have been entitled to receive sufficient financial compensation or have their land restored. In order to meet their food needs, such successful litigants could use the restituted land to embark on commercial farming (for income) or produce food for subsistence. ${ }^{79}$ Otherwise, they could acquire an alternative land for commercial or subsistence agriculture, especially in cases where they are granted compensation instead of restitution of land. Evidently, a financial pay-out equally provides a source of entitlement in terms of RTF. In summary, any interpretation of the above land legislations must take into cognisance individual and group's RTF as set out under sections 27 and 28 of the Constitution.

73 Land Reform Act 3 of 1996; ESTA supra; PIE supra.

74 Skuse \& Cousins "Spaces of resistance: informal settlement, communication and community organisation in a Cape Town township" 2007 US 979.

75 Hall \& Keep "Elite capture and state neglect: new evidence on South Africa's land reform” 2017 Review of African Political Economy (RAPE) 129.

76 Restitution of Land Rights Act 22 of 1994.

77 Department of Land Affairs $v$ Goedgelegen Tropical Fruits (Pty) Ltd CCT69/06 (unreported).

78 Department of Land Affairs $v$ Goedgelegen Tropical Fruits (Pty) Ltd supra para 53.

79 Karriem \& Hoskins "From the RDP and NDP: A critical appraisal of the developmental state, land reform, and rural development in South Africa" 2016 Politikon 328. 


\section{Parting shot: enforcement of the right to food}

Economic and social rights have not always been adequately recognised or properly protected by South African courts even in post-1994 (although they enjoy the status of full justiciable rights). Moreover, the enforcement of economic and social rights is confronted with government's lack of resources to meet, for instance, its RTF obligation. As a result, what is called for, is an activist judicial body which adopts a creative judicial decision which converts the RTF into reality while acknowledging resource scarcity. It is in this light that Scott and Alston aver that the purposive approach to RTF implies that judgments of the court should reflect the need to improve food security. ${ }^{80}$ The next section takes a closer look at some of the suggestions, which may be useful towards the enforcement of the RTF.

\section{Creative judicial remedies: hollow hope?}

Sections 38 and 172(1)(b) of the Constitution set out guidelines within which to produce creative judicial remedies relevant to RTF. ${ }^{81}$ These provisions oblige a court to prevent threat to, or actual infringement of, the RTF by granting "appropriate relief" or making an order that is "just, fair or equitable". 82 Considering the wide parameters provided in the Constitution, it then remains to identify relevant court remedies, which could best promote RTF. Such an assessment takes on greater relevance if one agrees with the notion espoused by leading legal scholars, that to date there is a lack of effective remedies to give real impetus to the notion of "appropriate relief", in terms of socioeconomic rights. Against this backdrop, the forms of relief advocated out in Fose $v$ Minister of Safety and Security by Ackermann J could serve as a useful starting point in understanding the meaning of "appropriate relief". ${ }^{83}$ According to the judge, an appropriate relief is an order that is handed down to protect and enforce the Constitution. ${ }^{84}$ Depending on the circumstances of each particular case, a relief may be a declaration of rights, an interdict, a mandamus or such other relief as may be required to ensure that the rights enshrined in the Constitution are enforced. ${ }^{85}$

Given the almost lack of case law on RTF in South Africa, a useful starting point for enforcing it may be a declaration of rights which indicates the nature and extent of this right. It may be useful for a court deciding on an application brought by the food insecured to set out the scope of the right by means of a declaration. Nonetheless, without a

80 Scott \& Alston "Adjudicating constitutional priorities in a transnational context: A comment on Soobramoney's legacy and Grootboom's promise" 2000 SAJHR 217.

81 Constitution ss $38 \& 172(1)(b)$.

82 Constitution ss $38 \& 172(1)(\mathrm{b})$.

83 Fose $v$ Minister of Safety and Security (1997) 3 SA 786 (CC).

84 Fose $v$ Minister of Safety and Security supra.

8519973 SA 786 (CC) para 19 
further guideline as to how to realise this right in practice, a declaration of rights would ultimately be an inadequate remedy. ${ }^{86}$

Moreover, the granting of an interdict or mandamus by a court could appear to address the question of a more practical judicial remedies concerning the RTF. The handing down of these (provisional) remedies would cause private entities or individuals (in some cases), or the relevant state functionary to do the needful, or terminate their unconstitutional conduct which infringes on people's RTF. An important precedent for this remedy could be traced to the Grootboom judgment where the court issued a declaratory order requiring the government to meet its constitutional obligations under section 26(2) of the Constitution. ${ }^{87}$ Yet, as demonstrated in the case, judicial remedies in the form of mandamus or interdicts with no order as to what steps must be adopted or avoided similarly fails to sufficiently take the matter further. Consequently, when handing down appropriate relief related to socioeconomic rights, courts must include an order guiding the executive and legislature to introduce reforms in accordance with their respective mandates. Further, the judiciary must maintain a supervisory role of monitoring the operationalisation of orders, specifically be ensuring that the actions of these two arms of government are reasonable, logical and tailored towards the promotion of the RTF. ${ }^{88}$

Apparently, even more useful is the concept of supervisory jurisdiction of state compliance with the order of the court. There is always the problem of executive's failure to comply with the order of the judiciary, as was clearly demonstrated in the Grootboom case. In this case, there was clearly lack of monitoring and follow-up by the (quasi)judicial institution to ensure that the government fully complies with the decision of the court. ${ }^{89}$ The lack of monitoring evidently resulted in the state's non-fulfilment of the remedies accorded to the victims for more than two years after the judgment. 90

Besides the judiciary, it is important that a Chapter nine institution periodically monitors state's compliance of court's decisions. Thereafter, at a particular date, such a Chapter nine institution should be mandated to report its findings to the court (ideally the court which made the decision) concerning the degree of enforcement of the order by the state. $^{91}$ The court order should, moreover, mandate the Chapter nine institution to send feedback at an earlier date, especially in cases where

86 Scott \& Alston 2000 SAJHR 218.

87 Grootboom supra.

88 Mbazira "Non-implementation of court orders in socio-economic rights litigation in South Africa: is the cancer here to stay?" 2008 ESR Review 5.

89 Mbazira 2008 ESR Review 7.

90 Mbazira 2008 ESR Review 5.

91 Nthai "Implementation of socio-economic rights in South Africa" 1999 De Rebus 41. 
non-compliance by the state poses serious threats to the applicant(s) and victims involved. ${ }^{92}$

It is important to shed more light on the proposed supervisory role of Chapter nine institutions, especially in terms of gathering and evaluating information. ${ }^{93}$ In the course of the assessment of compliance, it is imperative that officials of the state department whose compliance with a judicial decision is under scrutiny are not allowed to be part of the assessors. Such independent and objective evaluation is crucial for true impartiality and accountability in the assessment process. ${ }^{94}$ In Grootboom, the lack of monitoring and enforcement implied that although in theory the SAHRC was mandated by the court to play a supervisory role, it was unable to effectively execute this mandate, given that it could not access all the relevant information relating to the enforcement of the court's decision in all the provinces. ${ }^{95}$ It is submitted that in order to avert a recurrence of such a setback in a RTF situation, the supervisory body should be mandated by the court to gather information independently of government department reports. It is in view of this constraint that the SAHRC advocated for the effective monitoring of government's programmes to determine the extent to which the RTF has been realised or violated. ${ }^{96}$

To further ensure greater performance or compliance, it is important for a court to clearly set out precise duration within which its orders are complied with. This could be achieved by setting out precise timeframes for compliance by the state. Thus, in the context of the RTF, if a court decides that the current school feeding programme is inadequate, then it must set out specific deadlines within which specific benchmarks must be met. In the process of setting out such deadlines, it must consider section $27(2)$ of the Constitution which relates to resource limitation. ${ }^{97}$

It is important to indicate that monitoring of compliance and timeframes for fulfillment of court order are inextricably linked, given that where deadlines have been set for fulfillment of different parts of the judgement, it becomes significantly easier to monitor compliance. ${ }^{98}$ For instance, drought victims could successfully argue that the state has failed to adopt adequate measures (preventive and reactive) measures to

92 It could be said that the SAHRC's expansive mandate under s184 of the Constitution makes it well placed to address socio-economic rights challenges.

93 Nkrumah 98.

94 Rideout et al "Bringing home the right to food in Canada: challenges and possibilities for achieving food security" 2007 PHN 569.

95 Nkrumah 108

96 SAHRC "SAHRC - Economic and Social Rights - The Right to Food" (2004) http://www.sahrc.org.za/home/21/files/Reports/5th_esr_food.pdf (last accessed 2019-04-08).

97 Constitution s 27(2).

98 Tushnet "The Issue of State Action/horizontal Effect in Comparative Constitutional Law" 2003 International Journal of Constitutional Law (IJCL) 87. 
address their urgent need. ${ }^{99}$ The question then arises how long it should take the state to launch a suitable programme to meet its obligation under sections 27 and 28. ${ }^{100}$ This question could satisfactorily be addressed by a court order setting out the deadline for enforcement of its order. ${ }^{101}$ It must be noted that the poor track record of the state in conforming to court orders provides the impetus for the inclusion of deadlines for enforcement. ${ }^{102}$ The urgent need for the inclusion of deadlines to court orders is reinforced especially by sections 27 and 28 of the Constitution, given that an unreasonable delay in enforcement may result in serious circumstances, such as undernourishment and in some instances death. As discussed below, the inclusion of deadlines for government conformity is an important component of framework legislation relating to the RTF.

In summary, for the court to achieve effective implementation of its orders, such an order must set out: (i) deadlines for implementation of the order; (ii) what should be contained in a report on the steps adopted to conform to the order; and (iii) how monitoring of implementation will take place. Any order without these indicators runs the risk of being considered questionable, considering that while the RTF under sections 27 and 28 of the Constitution may be, in theory, progressive, yet, in practice the food poor continue to be subjected to chronic hunger.

\section{Setting the agenda: Reflections on right to food advocacy}

In order to effectively enforce economic and social rights, specifically the RTF, there is a need for awareness creation backed by financial resource to enable the food poor litigate. It was in this regard that the SAHRC touted that the widespread ignorance of what key socioeconomic rights entail has exacerbated the difficulty in realising them. ${ }^{103}$ This constraint could be traced to the inadequate legal education among victims of socioeconomic rights violation, as well as lack of funding for civil society organisations (CSOs) to advocate, educate and assist the food poor seek redress in court.

99 Van Rensburg \& Naudé "Human Rights and Development: The Case of Local Government Transformation in South Africa” 2007 PAD 394

100 Klug "Five Years On: How Relevant is the Constitution to the New South Africa" 2001 VLR 803.

101 Huchzermeyer "Housing rights in South Africa: invasions, evictions, the media, and the courts in the cases of Grootboom, Alexandra, and Bredell" 2003 UF 85.

102 One of the cases where the government responded slowly to the judgement of the court was Bacela $v$ MEC for Welfare (Eastern Cape Provincial Government) [1998] 1 All SA 525 (E).

103 SAHRC “Economic \& social rights report: sangoco's report on poverty and human rights vol V" 1997 https://www.sahrc.org.za/home/21/files/Reports/ ESR \% 20Sangogo \% 20Report \% 20on \% 20Poverty \% 20and \% 20Human \% 20 Rights 1997-1998.pdf (last accessed 2019-04-08) 37. 
It is in this light that the SAHRC averred that the key to effective realisation of economic and social rights specifically the RTF is improved advocacy or education. ${ }^{104}$ It is, therefore, imperative that relevant NGOs and social movements constantly launch an across-the-board campaign on issue of RTF. Such a campaign could face potential threats of lack of resources for advocacy or litigation in courts. Hence, it is important for organisers of such initiatives to draw inspiration from some of the strategies adopted by successful CSOs such as the Treatment Action Campaign (TAC) in advocating free treatment for HIV/AIDS patients. ${ }^{105}$ Such innovative strategies of TAC worth emulating stretch from fundraising activities, strategic litigation to enhanced collaboration between social movements and NGOs. ${ }^{106}$

\section{Conclusion}

South Africa is confronted with serious challenge of food poverty. In view of the recent data on chronically hungry, it could be said that the policies and programmes of the government are woefully insufficient in addressing this crisis. Probably, this problem is not because of incapacity or lack of political will to realise the RTF, but because there is poor operationalisation of the various government efforts that are aimed at ensuring the fulfilment of the RTF.

This article has analysed a range of possible remedies that are likely to positively impact on the realisation of people's RTF, including a court claim to the constitutionality of current food interventions. Such a claim must contest the exclusion of millions of food insecured South Africans from existing SAP and other food related programmes. To serve as an incentive to efficiently roll out programmes thereafter, costs should be sought against the state in each application. As indicated above, the broad nature of the RTF undoubtedly calls for a multi-faceted approach towards the protection, promotion and fulfilment of sections 27 and 28 of the Constitution. In order to effectively address the current chronic hunger situation, the government's efforts must encompass inputs from all arms of government, namely, the judiciary, legislative and executive. It is important that these organs collaborate in closing the gap between the theory and operationalisation of the RTF.

104 SAHRC 1997 https://www.sahrc.org.za (last accessed 2019-04-08) 37.

105 Friedman \& Mottiar "A rewarding engagement? The treatment action campaign and the politics of HIV/AIDS" 2005 Politics \& Society 514.

106 Friedman \& Mottiar 2005 Politics \& Society 517. 